\title{
Identifying children with persistent asthma from health care administrative records
}

\author{
Anita L Kozyrskyj PhD ${ }^{1,3}$, Cameron A Mustard ScD ${ }^{1,2}$, Allan B Becker MD 3
}

\begin{abstract}
AL Kozyrskyj, CA Mustard, AB Becker. Identifying children with persistent asthma from health care administrative records. Can Respir J 2004;11(2):141-145.
\end{abstract}

BACKGROUND: Investigation into the origins of asthma is contingent on definitions of asthma, which can differentiate asthma from transient wheezing syndromes in children.

OBJECTIVES: This research was undertaken to develop a definition for asthma derived from health care administrative records, which would identify children with persistent asthma.

PATIENTS AND METHODS: Using population-based, health care administrative data, children with possible asthma were identified as having one or more physician visits or hospitalizations for asthma or bronchitis diagnoses from January 1995 to December 1995, or, in the absence of asthma-like diagnoses, one or more prescriptions for asthma prophylaxis drugs or ketotifen concomitant with a betaagonist, or two or more prescriptions for beta-agonists.

RESULTS: The likelihood of persistent asthma, defined as repeated health care and prescription use for asthma from 1996 to 1998, was assessed for various asthma markers and risk factors in 29,198 children with possible asthma. Children with asthma prescription drugs or asthma health care use not limited to the winter season were three to six times more likely than children without these characteristics to have persistent asthma. The likelihood of persistent asthma was elevated to a substantial degree in the presence of both of these markers.

CONCLUSIONS: The inclusion of these measures in a diagnosisbased definition improves the ability to identify persistent asthma in children.

Key Words: Asthma; Child; Databases; Drug; Epidemiology; Prescriptions

Tnestigation into the origins of asthma is contingent on 1 valid definitions of childhood asthma $(1,2)$. Numerous definitions have been used (3). Symptom-based definitions of asthma are reproducible (4-6), but cannot distinguish asthma from transient wheezing syndromes $(3,7,8)$. Measures based on physician diagnoses of asthma are subject to similar limitations and have the potential caveat of biased assignment of diagnosis (9-11). Physiological measures, such as bronchial reactivity tests, are highly correlated with the underlying inflammatory
Le dépistage des enfants atteints d'asthme permanent à partir des dossiers de santé administratifs

HISTORIQUE : Les explorations sur les origines de l'asthme dépendent des définitions de l'asthme, qui peuvent distinguer l'asthme des syndromes de wheezing transitoire chez l'enfant.

OBJECTIFS : La présente recherche a été entreprise pour élaborer une définition de l'asthme dérivée des dossiers de santé administratifs permettant de dépister les enfants atteints d'asthme permanent.

PATIENTS ET MÉTHODOLOGIE : Au moyen de dossiers administratifs de santé de la population, des enfants susceptibles de souffrir d'asthme ont été dépistés selon au moins une consultation auprès d'un médecin ou au moins une hospitalisation découlant d'un diagnostic d'asthme ou de bronchite entre janvier et décembre 1995 ou, en l'absence de diagnostic semblable à l'asthme, au moins une ordonnance de médicament en prophylaxie de l'asthme ou de kétotifène prescrit conjointement avec un béta-agoniste ou au moins deux ordonnances de béta-agoniste.

RÉSULTATS : La probabilité d'asthme permanent, défini comme des soins répétés et le recours à des prescriptions contre l'asthme entre 1996 et 1998, a été évaluée selon divers marqueurs et facteurs de risque d'asthme chez 29198 enfants peut-être asthmatiques. Les enfants à qui on avait prescrit des médicaments contre l'asthme ou qui avaient reçu des soins à cet égard au cours d'autres saisons que la saison hivernale étaient de trois à six fois plus susceptibles de souffrir d'asthme permanent que les autres. La probabilité d'asthme permanent augmentait à un degré substantiel en présence de ces deux marqueurs.

CONCLUSION : L'inclusion de ces mesures dans une définition diagnostique améliore la capacité de dépister l'asthme permanent chez les enfants.

\footnotetext{
${ }^{1}$ Department of Community Health Sciences, Manitoba Centre for Health Policy, University of Manitoba, Winnipeg, Manitoba; ${ }^{2}$ Department of Public Health Sciences, University of Toronto, and Institute for Work and Health, Toronto, Ontario; ${ }^{3}$ Department of Pediatrics and Child Health, University of Manitoba, Winnipeg, Manitoba

Correspondence: Dr Anita L Kozyrskyj, Manitoba Centre for Health Policy, 408 - 727 McDermot Avenue, Winnipeg, Manitoba R3E 2 P5.

Telephone 204-789-3264, fax 204-789-3910, e-mail kozyrsk@cc.umanitoba.ca
} 
The inclusion of factors that predict persistent asthma versus transient wheezing, such as history of allergy and the presence of year-round symptoms, have the potential to further improve validity $(7,21-24)$. Health care administrative records, which can be linked longitudinally to create histories of health care use (25), hold promise in testing the predictive value of these definitions in differentiating transient wheezing from persistent asthma. The objective of this research was to identify measures from population-based health care administrative records that predict persistent asthma in children.

\section{PATIENTS AND METHODS}

Data for this study were obtained from four population-based, electronic databases maintained by the Manitoba Health Services Insurance Plan (MHSIP): registration files, physician reimbursement claims for diagnosis information, hospital discharge abstracts for diagnosis information and records of prescriptions dispensed in retail pharmacies. The study protocol was approved by the Health Research Ethics Board, University of Manitoba (Winnipeg, Manitoba) and the Manitoba Health Access and Confidentiality Committee.

The MHSIP registration files contain records for every individual eligible to receive insured health services, and records of birth date, sex and geographical location. Records of physician reimbursement for medical care provided are submitted under a fee-forservice arrangement and contain information on patient diagnosis at the three-digit level of the International Classification, Ninth Edition, Clinical Modification (ICD-9-CM) classification system and physician specialty. Discharge abstracts for hospital services include information on up to 16 ICD-9-CM diagnostic codes, of which the first diagnosis is the primary diagnosis responsible for the hospital stay. Prescription records, which are submitted by retail pharmacies for reimbursement by provincial drug insurance plans and for drug use review purposes, contain data on the date of prescription dispensing, drug name and identification number, dose form and quantity dispensed. The reliability and validity of the MHSIP databases have been shown to be high for describing population drug use and health care contact for specific conditions $(26,27)$. The prescription database captures virtually all prescriptions dispensed in retail pharmacies. Record links among databases were created using anonymous personal identifiers to create longitudinal histories of health care use.

Children, aged five to 15 years in January 1995 and registered with the MHSIP until March 1998, were identified as having possible asthma on the basis of the following, documented in the MHSIP's databases from January to December 1995: at least one physician visit or hospitalization (primary diagnostic field) for asthma-like diagnoses (asthma, ICD-9 code 493; bronchitis, ICD9 codes 490 and 491; bronchiolitis ICD-9 code 466); in the absence of these diagnoses, at least one prescription for an inhaled corticosteroid (beclomethasone, budesonide, fluticasone) or cromone, for ketotifen concomittant with an inhaled or oral betaagonist (salbutamol, fenoterol), or two or more prescriptions for an inhaled or oral beta-agonist. Asthma-like conditions were included to prevent exclusion of children with asthma, but who were diagnosed with bronchitis $(24,28)$. The definition excluded children with singular use of bronchodilators and no asthma diagnosis (16).
Using the cohort of children with possible asthma, several validity assessments were undertaken to refine further the asthma definition. These included comparisons with survey estimates of asthma prevalence reported in the literature, cross-validation of the drug and diagnosis components of the definition, and tests of discriminant construct validity to differentiate between persistent asthma and not persistent asthma (29). Persistent asthma was defined as repeated physician visits or hospitalizations for asthma-like conditions or prescriptions for asthma drugs. It was applied to health care administrative records of children with possible asthma as follows: at least one health care visit for an asthma-like condition (asthma, bronchitis, bronchiolitis) or one prescription for an asthma drug (inhaled or oral beta-agonist, corticosteroid or cromone) in the next two years, January 1996 to March 1998. Not persistent asthma was defined as the absence of these criteria. For the cross-validation exercise, the proportion of children with asthma prescription drugs who also had an asthma diagnosis was determined. The prescription of an asthma drug was used as the gold standard, because all children with asthma are treated with asthma drugs at some point, especially children experiencing current symptoms $(17,18)$.

The discriminant construct validity analysis identified database-derived asthma markers or risk factors that distinguished between persistent and not persistent asthma (30). The purpose of this analysis was to identify predictors of persistent asthma that could be added to enhance health care database definitions of asthma in children. A cohort of children with health care for asthmalike conditions or asthma drug prescriptions from January to December 1995 was followed longitudinally to identify children with persistent asthma, as defined in the previous paragraph. The likelihood (odds ratio) of persistent versus not persistent asthma for individual measures was determined from multivariate logistical regression models. All measures were derived from health care and prescription databases for the calendar year 1995, with the exception of those that were assessed from the time of birth. In addition to physician diagnosis (at least one asthma diagnosis versus bronchitis diagnoses only since birth) and prescription drug measures (at least one inhaled beta-agonist [salbutamol, fenoterol], at least one maintenance drug such as inhaled corticosteroids [beclomethasone, budesonide, fluticasone] or cromones, at least one oral corticosteroid), the following measures were tested in the multivariate models: age, sex, prematurity status at birth (gestational age 36 weeks or less or a diagnosis of prematurity, respiratory distress syndrome or bronchopulmonary dysplasia within one year of birth recorded in hospitalization records), time since first health care contact for an asthma-like condition, number of hospitalizations per year for asthma-like conditions from birth to January 1995, physician visits or hospitalizations for allergic disorders (eg, hayfever, eczema) and pattern of health care use $(1,9,19,20,22,23,31-34)$. The latter measure classified children as having winter-only health care for asthma-like conditions or asthma drug prescriptions, or not winter-only health care if health care use was not limited to the winter season (November to February) $(21,24)$. Low-income neighbourhood status (from Census 1996 household income data [35-37]), treaty Indian status and singleparent, income-assisted household status were included in models to adjust for sociocultural differences in health care use (38). Aside from age, number of hospitalizations and time since first contact, study measures were added to regression models in the categorical format. The logistical regression analysis was conducted using the 
TABLE 1

Sensitivity and specificity of asthma diagnoses using asthma drugs as the gold standard (children in 1995)

\begin{tabular}{lccc}
\hline & $\begin{array}{c}\text { Asthma drug } \\
\text { prescription (n) }\end{array}$ & $\begin{array}{c}\text { No asthma drug } \\
\text { prescription (n) }\end{array}$ & Total (n) \\
\hline $\begin{array}{c}\text { Asthma-like } \\
\text { diagnosis }\end{array}$ & $11,514^{*}$ & 13,626 & 25,140 \\
$\begin{array}{c}\text { No asthma-like } \\
\text { diagnosis }\end{array}$ & 4058 & $145,010^{\dagger}$ & 149,068 \\
Total & 15,572 & 158,636 & 174,208 \\
\hline
\end{tabular}

"Sensitivity $=11,514 / 15,572 \times 100=73.9 \%$; ${ }^{\text {SPecificity }}=145,010 / 158,636 \times$ $100=91.4 \%$

TABLE 2

Likelihood of persistent asthma* in children with asthma diagnoses and asthma drug prescriptions, 1995

\begin{tabular}{|c|c|c|}
\hline Measure & $\begin{array}{l}\text { Children with } \\
\text { persistent } \\
\text { asthma (\%) }\end{array}$ & $\begin{array}{l}\text { Adjusted }{ }^{\dagger} \text { odds ratio } \\
\text { for asthma diagnosis } \\
\text { or drug versus } \\
\text { none }(95 \% \mathrm{Cl})\end{array}$ \\
\hline Asthma diagnosis $(n=18,955)$ & 75.5 & $1.72(1.61$ to 1.84$)$ \\
\hline Bronchitis diagnosis $(n=10,243)$ & 33.3 & 1.00 reference \\
\hline Inhaled beta-agonists $(n=15,669)$ & 84.3 & 5.51 (5.16 to 5.88$)$ \\
\hline No beta-agonists $(n=13,529)$ & 33.2 & 1.00 reference \\
\hline Maintenance drugs $^{\ddagger}(n=10,690)$ & 86.6 & 2.71 (2.51 to 2.92$)$ \\
\hline No maintenance drugs $(n=18,508)$ & 45.7 & 1.00 reference \\
\hline Oral corticosteroids $(n=4796)$ & 93.0 & 6.59 (5.83 to 7.46$)$ \\
\hline No oral corticosteroids $(n=24,402)$ & 54.3 & 1.00 reference \\
\hline
\end{tabular}

${ }^{*}$ Health care for asthma-like diagnoses and prescriptions for asthma drugs in 1996 to 1998; 'Adjusted for treaty Indian status, single-parent, incomeassisted households and neighbourhood income, and all measures in Table; $¥$ Inhaled corticosteroids, sodium cromoglycate, ketotifen and salmeterol

stepwise forward elimination process, and variables were retained at the $95 \%$ level of confidence.

\section{RESULTS}

Among 174,208 Manitoba children aged five to 15 years, 25,140 $(14.4 \%)$ had at least one physician visit or hospitalization attributed to an asthma-like condition over the time period from January 1995 to December 1995. Over the same time period, 15,572 (8.9\%) had received at least one prescription for an asthma drug (excluding singular use of bronchodilators). A total of 29,198 children or $17 \%$ of Manitoba children met the case definition for possible asthma, based on the presence of asthmalike diagnoses or asthma prescription drugs. Seventy-four per cent of children with an asthma drug prescription had a health care visit for an asthma-like diagnosis in the calendar year 1995, known as sensitivity (Table 1 ). In the absence of a prescription for an asthma drug, 91\% of children had no health care contact for asthma-like diagnoses (known as specificity). Sixty per cent of the 29,198 children followed longitudinally had further health care use during 1996 to 1998, corresponding to a prevalence of $10 \%$ of children with persistent asthma.

Children with asthma diagnoses were almost twice as likely as children with bronchitis diagnoses only to have persistent asthma (Table 2). However, one-quarter of the children with a physician diagnosis of asthma did not have persistent
TABLE 3

\begin{tabular}{|c|c|c|}
\hline Measure & $\begin{array}{l}\text { Adjusted }{ }^{\dagger} \\
\text { odds ratio }\end{array}$ & $95 \% \mathrm{Cl}$ \\
\hline \multicolumn{3}{|l|}{ Asthma diagnosis and } \\
\hline Winter-only use plus no asthma drugs & 1.00 & Reference \\
\hline Not winter-only use plus no asthma drugs & 5.66 & 4.90 to 6.53 \\
\hline Not winter-only use plus inhaled beta-agonist & 31.1 & 26.4 to 36.7 \\
\hline Not winter-only use plus maintenance drug $\ddagger$ & 11.4 & 7.90 to 16.5 \\
\hline Not winter-only use plus oral corticosteroid & 19.3 & 14.9 to 24.8 \\
\hline \multicolumn{3}{|l|}{ Bronchitis diagnosis§ and } \\
\hline Winter-only use plus no asthma drugs & 1.00 & Reference \\
\hline Not winter-only use plus no asthma drugs & 3.91 & 3.48 to 4.40 \\
\hline Not winter-only use plus inhaled beta-agonist & 14.9 & 12.6 to 17.6 \\
\hline Not winter-only use plus maintenance drug $\ddagger$ & 5.24 & 3.79 to 7.26 \\
\hline Not winter-only use plus oral corticosteroid & 45.4 & 34.4 to 59.8 \\
\hline Female & 1.00 & Reference \\
\hline Male & 0.93 & 0.87 to 0.99 \\
\hline Absence of health care for allergic diagnoses & 1.00 & Reference \\
\hline Presence of health care for allergic diagnoses & 1.29 & 1.21 to 1.37 \\
\hline $\begin{array}{l}\text { Asthma or bronchitis hospitalizations per year } \\
\text { from birth (increase in number) }\end{array}$ & 2.26 & 1.72 to 2.98 \\
\hline $\begin{array}{l}\text { Time since first contact for asthma/bronchitis } \\
\text { (year increase) }\end{array}$ & 1.05 & 1.03 to 1.06 \\
\hline Age (one year increase) & & NS \\
\hline
\end{tabular}

*Health care for asthma-like diagnoses and prescriptions for asthma drugs in 1996 to 1998; 'Adjusted for treaty First Nations status, low neighbourhood income status, single-parent, income-assisted household status and all measures in Table; \#Inhaled corticosteroid, sodium cromoglycate, ketotifen and salmeterol; §Bronchitis, but no asthma diagnosis since birth. NS Not significant

asthma. The presence of an asthma prescription drug was associated with persistent asthma (eg, $\mathrm{OR}=5.5$ for beta-agonists) to a greater extent than having an asthma diagnosis $(\mathrm{OR}=1.7)$. In the full multivariate model (Table 3$)$, children with asthma or bronchitis diagnoses and no asthma drugs were fivefold more likely to have persistent asthma if they did not have winter-only rather than if they had winter-only health care use for asthma. Not having winter-only use for asthma, concomittant with an asthma drug prescription, increased the likelihood of persistent asthma in children to a substantial degree, especially in children with bronchitis diagnoses and prescriptions for oral corticosteroids. Other risk factors, such as history of allergy, longer duration since first physician contact for asthma and a greater number of previous hospitalizations for asthma, were independently associated with persistence of asthma. Prematurity increased the likelihood of persistent asthma in univariate but not multivariate analyses (data not shown).

\section{DISCUSSION}

Among 174,000 Manitoban schoolchildren, 29,198 children (17\%) had health care contacts for asthma-like diagnoses or received asthma drug prescriptions during 1995. Similarly, a population-based survey in the United Kingdom reported a prevalence of wheezing in children aged five to 17 years of $13 \%$ to $17 \%$ (17). Further, the 1995 to 1996 Student Lung Health Survey (39) reported that 11\% of Winnipeg schoolchildren diagnosed with asthma, and a further $20 \%$ of students 
never diagnosed with asthma, had asthma-like symptoms or received asthma drugs. In our cross-validation analysis, asthmalike diagnoses were present in $74 \%$ of children receiving prescriptions for asthma drugs over a one-year period. Others have reported a medical record diagnosis of asthma in $80 \%$ of persons receiving asthma drug prescriptions over a three-year period; for an asthma-like condition, the per cent agreement was $100 \%(5,18,40)$. Our lower rate of agreement is likely the outcome of asthmatic children receiving asthma drugs but not seeing a physician that year. Surveys report that $90 \%$ of schoolchildren had taken their asthma drugs in the past year, but only $70 \%$ had seen their physician $(5,39)$. In addition, children with asthma drugs but no health care visits were potentially using the emergency room for health care, data which are not completely captured by Manitoba's health care administrative databases. Thus, the inclusion of data on asthma prescription drugs in the asthma definition identified $14 \%$ of children with asthma that otherwise would have been excluded if a diagnosisbased definition had been used. This is an important finding, because many health care databases do not contain information on prescriptions dispensed for whole populations of children (41).

Compatible with the natural history of wheezing in childhood, $60 \%$ of children treated for asthma in 1995 had contact with the health care system three years later $(1,8)$. The corresponding prevalence for persistent asthma is close to the $11 \%$ of Winnipeg schoolchildren with current asthma in the 1995 to 1996 Student Lung Health Survey. Discriminant validity analysis identified a list of factors that were associated with persistent asthma, a construct that has been used to distinguish asthma from transient wheezing syndromes (22). Children with prescriptions for inhaled beta-agonists or oral corticosteroids were five to six times more likely, and children with maintenance drug prescriptions were three times more likely, to have persistent asthma than children without asthma drug prescriptions. Current use of an inhaled betaagonist or an oral corticosteroid may indicate continued symptoms or exacerbation of asthma (42). Maintenance drugs such as inhaled corticosteroids are very effective in preventing asthma exacerbations (43), but not all asthmatic children are prescribed these drugs or are compliant with their use $(40,44)$. Although the association was of a lesser magnitude, independent of drug therapy, the likelihood of persistent asthma was almost two-fold greater in the presence of an asthma diagnosis than in its absence. Toelle et al's (19) longitudinal evaluation of three case definitions for childhood asthma showed that children diagnosed with asthma were more likely to have severe asthma 10 years later than children with wheezing symptoms who had not received a diagnosis of asthma.

The presence of risk factors for asthma, as measured by health care administrative records, was associated with an increased likelihood of persistent asthma. A history of allergy is a well-known risk factor for the development of asthma and distinguishes children with transient wheezing from those with asthma $(22,31)$. Other risk factors for persistent asthma, such as longer duration since first health care contact for asthmalike diagnoses and higher number of asthma hospitalizations at an earlier age, have also been documented $(19,24,34)$. Prematurity at birth was not a significant predictor in the multivariate model but potentially was correlated with other risk factors (33). Not winter-only health care use for asthma-like diagnoses or asthma drug prescriptions was associated with persistent asthma to a substantial degree. This finding is compatible with clinical observations of wheezing in children; children with asthma have year-round symptoms, whereas those with transient wheezing have winter-only symptoms $(24,45)$. Moreover, it has been recently documented that children with viral-associated wheeze in the winter season have different airway inflammatory cells than children with continuous wheezing (21). We translated the concept of year-round asthma symptom occurrence into the measure of not winter-only asthma health care use patterns, with the anticipation that it would be associated with asthma persistence. Due to the strength of the association between not winter-only health care use patterns and persistent of asthma, we believe that this measure would be a valuable addition to the case definition of asthma in childhood.

Two methodological issues arise when health care database records are used to define childhood asthma: under-representation subsequent to children not seeing their physician regularly and over-representation when asthma diagnoses are assigned to children who present with transient wheezing syndromes and not asthma. We addressed the former by including in the asthma definition, information on asthma prescription drugs, as well as diagnosis data from health care visits for asthma. In terms of diminishing the potential for over-representation, we used the longitudinal capabilities of the health care administrative databases to identify the persistence of asthma, defined as repeated health care use for asthma. This definition of persistent asthma has some limitations, especially when classifying repeated use of beta-agonist prescriptions in the absence of asthma diagnoses or other asthma drugs. We potentially misclassified 372 children as having persistent asthma on the basis of multiple prescriptions of beta-agonists, when, in fact, these children may have had isolated episodes of respiratory tract infections that were not asthma. Measures such as not winteronly health care use may help to resolve some of these issues. For example, based on our analysis, children with bronchitis diagnoses, which traditionally have been excluded from definitions of 'pure' asthma (9), could have asthma if there is concomittant use of asthma drug prescriptions, health care visits for allergic disorders or not winter-only health care use for bronchitis.

\section{CONCLUSIONS}

We have identified markers from health care use records that can be used to form a case definition of persistent asthma in children. To further assess the validity of this case definition, we are in the process of recruiting children for clinical assessment of asthma and linking this data to health care administrative records.

ACKNOWLEDGEMENTS: Anita L Kozyrskyj was supported by a PhD Fellowship Award from the National Health Research and Development Program, Health Canada. 


\section{REFERENCES}

1. Barbee RA, Murphy S. The natural history of asthma.

J Allergy Clin Immunol 1998;102:S65-72.

2. McDowell I, Newell C. The theoretical and technical foundations of health measurement. In: McGill G, Newell C, eds. Measuring Health: A Guide to Rating Scales and Questionnaires. New York: Oxford University Press, 1996:10-46.

3. Martinez FD, Helms PJ. Types of asthma and wheezing. Eur Respir J Suppl 1998;27:3S-8S.

4. O'Connor GT, Weiss ST. Clinical and symptom measures. Am J Respir Crit Care Med 1994;149:S21-8.

5. Kljakovic M. A comparison of the respiratory care given to asthmatic and nonasthmatic children in a general practice. N Z Med J 1994;107:240-2.

6. Beard CM, Yunginger JW, Reed CE, O'Connell EJ, Silverstein MD. Interobserver variability in medical record review: An epidemiological study of asthma. J Clin Epidemiol 1992;45:1013-20.

7. Stein RT, Holberg CJ, Morgan WJ, et al. Peak flow variability, methacholine responsiveness and atopy as markers for detecting different wheezing phenotypes in childhood. Thorax 1997;52:946-52.

8. Anderson HR, Bland JM, Patel S, Peckham C. The natural history of asthma in childhood. J Epidemiol Community Health 1986;40:121-9.

9. Erzen D, Carriere KC, Dik N, et al. Income level and asthma prevalence and care patterns. Am J Respir Crit Care Med 1997;155:1060-5.

10. Cunningham J, Dockery DW, Speizer FE. Race, asthma, and persistent wheeze in Philadelphia schoolchildren. Am J Public Health 1996;86:1406-9.

11. Bauman A, Young L, Peat JK, Hunt J, Larkin P. Asthma under-recognition and under-treatment in an Australian community. Aust N Z J Med 1992;22:36-40.

12. Enright PL, Lebowitz MD, Cockroft DW. Physiologic measures: Pulmonary function tests. Asthma outcome. Am J Respir Crit Care Med 1994;149:S9-18.

13. Hopp RJ, Townley RG, Biven RE, Bewtra AK, Nair NM. The presence of airway reactivity before the development of asthma. Am Rev Respir Dis 1990;141:2-8.

14. Pattemore PK, Asher MI, Harrison AC, Mitchell EA, Rea HH, Stewart AW. The interrelationship among bronchial hyperresponsiveness, the diagnosis of asthma, and asthma symptoms. Am Rev Respir Dis 1990;142:549-54.

15. Salome CM, Peat JK, Britton WJ, Woolcock AJ. Bronchial hyperresponsiveness in two populations of Australian schoolchildren. I. Relation to respiratory symptoms and diagnosed asthma. Clin Allergy 1987;17:271-81.

16. Roberts SJ, Bateman DN. Which patients are prescribed inhaled anti-asthma drugs? Thorax 1994;49:1090-5.

17. Strachan DP, Anderson HR, Limb ES, O'Neill A, Wells N. A national survey of asthma prevalence, severity, and treatment in Great Britain. Arch Dis Child 1994;70:174-8.

18. Neville RG, Bryce FP, Robertson FM, Crombie IK, Clark RA. Diagnosis and treatment of asthma in children: Usefulness of a review of medical records. Br J Gen Pract 1992;42:501-3.

19. Toelle BG, Peat JK, van den Berg RH, Dermand J, Woolcock AJ. Comparison of three definitions of asthma: A longitudinal perspective. J Asthma 1997;34:161-7.

20. Toelle BG, Peat JK, Salome CM, Mellis CM, Woolcock AJ. Toward a definition of asthma for epidemiology. Am Rev Respir Dis 1992;146:633-7.

21. Stevenson EC, Turner G, Heaney LG, et al. Bronchoalveolar lavage findings suggest two different forms of childhood asthma. Clin Exp Allergy 1997;27:1027-35.

22. Martinez FD, Wright AL, Taussig LM, Holberg CJ, Halonen M,
Morgan WJ. Asthma and wheezing in the first six years of life. The Group Health Medical Associates. N Engl J Med 1995;332:133-8.

23. Brooke AM, Lambert PC, Burton PR, Clarke C, Luyt DK, Simpson H. The natural history of respiratory symptoms in preschool children. Am J Respir Crit Care Med 1995;152:1872-8.

24. Wilson NM.The significance of early wheezing. Clin Exp Allergy 1994;24:522-9.

25. Cohen MM, Roos NP, DeCoster C, Black C, Decker KM. Manitoba's population-based databases and long-term planning: Beyond the hospital databases. Health Manage Forum 1995;8:5-23.

26. Kozyrskyj Al, Mustard CA. Validation of an electronic, populationbased prescription database. Ann Pharmacother 1998;32:1152-7.

27. Robinson JR, Young TK, Roos LL, Gelskey DE. Estimating the burden of disease: Comparing administrative data and self-reports. Med Care 1997;35:932-47.

28. Hueston WJ, Mainous AG. Acute bronchitis. Am Fam Physician 1998;57:1270-2.

29. West SL, Strom BL. Validity of pharmacoepidemiology drug and diagnosis data. In: Strom BL, ed. Pharmacoepidemiology. New York: Churchill Livingstone Inc, 1994:549-80.

30. Feinstein AR. Clinimetrics. New Haven: Yale University Press, 1987.

31. Wennergren G, Amark M, Amark K, Oskarsdottir S, Sten G, Redfors S. Wheezing bronchitis reinvestigated at the age of 10 years. Acta Paediatr 1997;86:351-5.

32. Dodge R, Martinez FD, Cline MG, Lebowitz MD, Burrows B. Early childhood respiratory symptoms and the subsequent diagnosis of asthma. J Allergy Clin Immunol 1996;98:48-54.

33. von Mutius E, Nicolai T, Martinez FD. Prematurity as a risk factor for asthma in preadolescent children. J Pediatr 1993;123:223-9.

34. Ulrik CS. Outcome of asthma: Longitudinal changes in lung function. Eur Respir J 1999;13:904-18.

35. Mustard CA, Roos NP. The relationship of prenatal care and pregnancy complications to birthweight in Winnipeg, Canada. Am J Public Health 1994;84:1450-7.

36. Wilkins R. Use of postal codes and addresses in the analysis of health data. Health Rep 1993;5:157-77.

37. Krieger N. Overcoming the absence of socioeconomic data in medical records: Validation and application of a census-based methodology. Am J Public Health 1992;82:703-10.

38. Halfon N, Newacheck PW. Childhood asthma and poverty: Differential impacts and utilization of health services. Pediatrics 1993;91:56-61.

39. Respiratory Disease Division, Bureau of Cardio-Respiratory Diseases and Diabetes, Laboratory Centre for Disease Control, Health Protection Branch, Health Canada. Childhood Asthma in Sentinel Health Units: Findings of the Student Health Survey 1995-1996. Ottawa: Health Canada, 1998.

40. Osborne ML, Vollmer WM, Johnson RE, Buist AS. Use of an automated prescription database to identify individuals with asthma. J Clin Epidemiol 1995;48:1393-7.

41. Miller E, Blatman B, Einarson TR. A survey of population-based drug databases in Canada. Can Med Assoc J 1996;154:1855-64.

42. Milgrom H, Bender B, Ackerson L, et al. Noncompliance and treatment faiure in children with asthma. J Allergy Clin Immunol 1996;98:1051-7.

43. Simons FE. A comparison of beclomethasone, salmeterol, and placebo in children with asthma. Canadian Beclomethasone DipropionateSalmeterol Xinafoate Study Group. N Engl J Med 1997;337:1659-65.

44. Warner JO. Review of prescribed treatment for children with asthma in 1990. BMJ 1995;311:663-6.

45. Dales RE, Schweitzer I, Toogood JH, et al. Respiratory infections and the autumn increase in asthma morbidity. Eur Respir J 1996;9:72-7. 


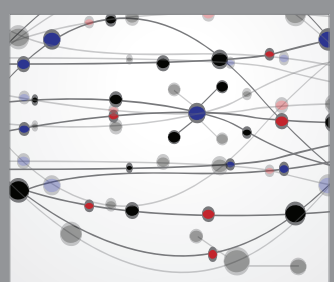

The Scientific World Journal
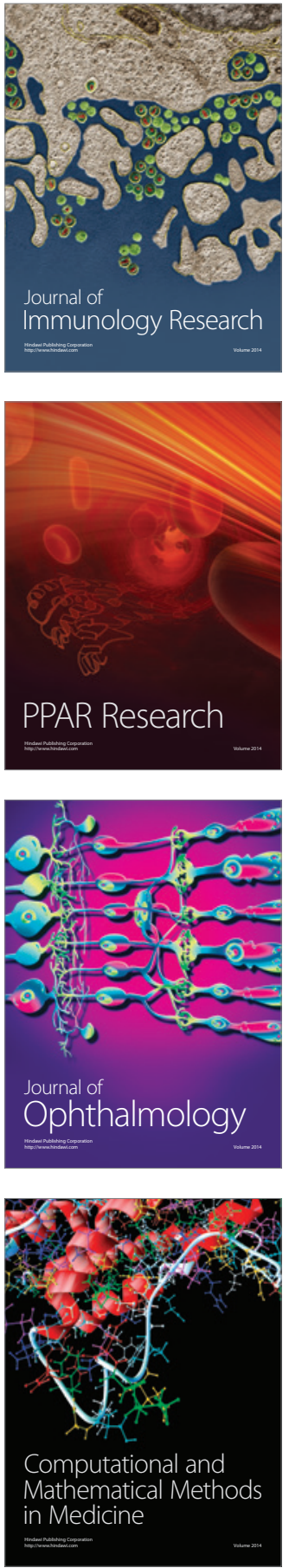

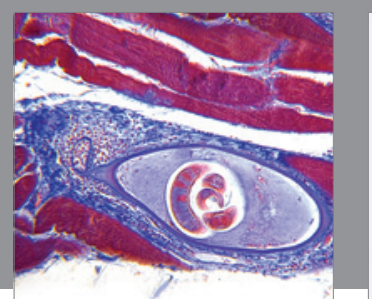

Gastroenterology Research and Practice

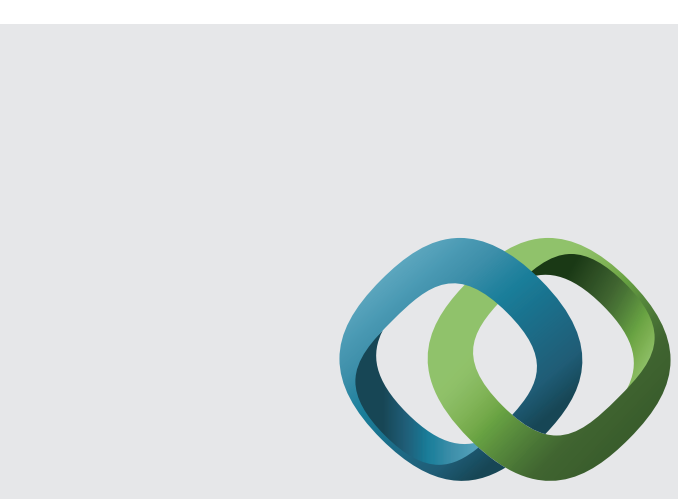

\section{Hindawi}

Submit your manuscripts at

http://www.hindawi.com
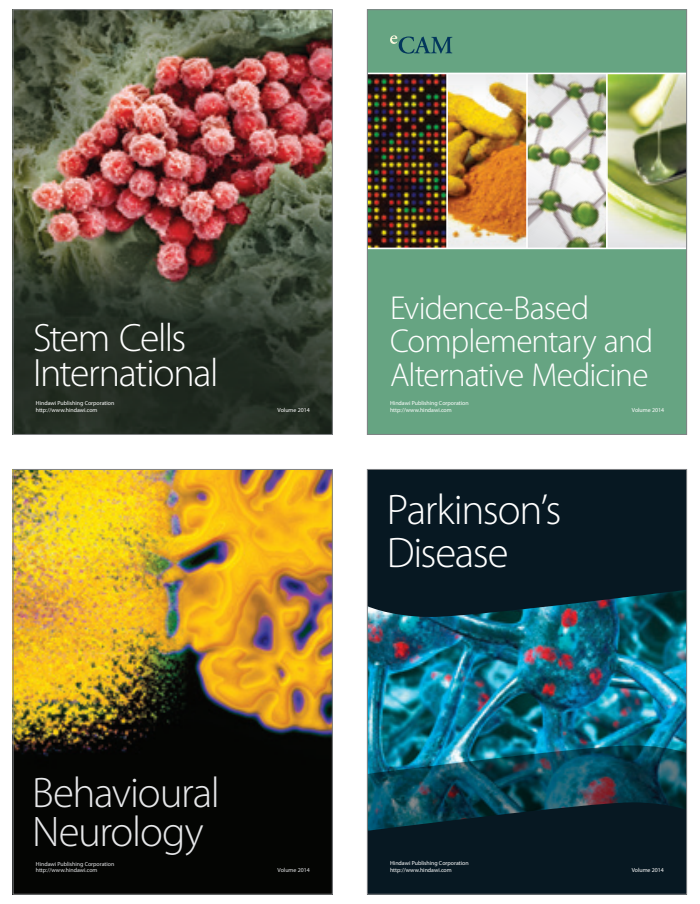
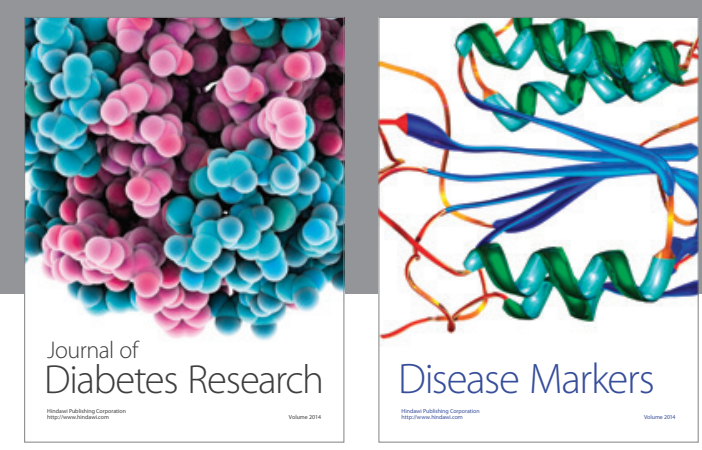

Disease Markers
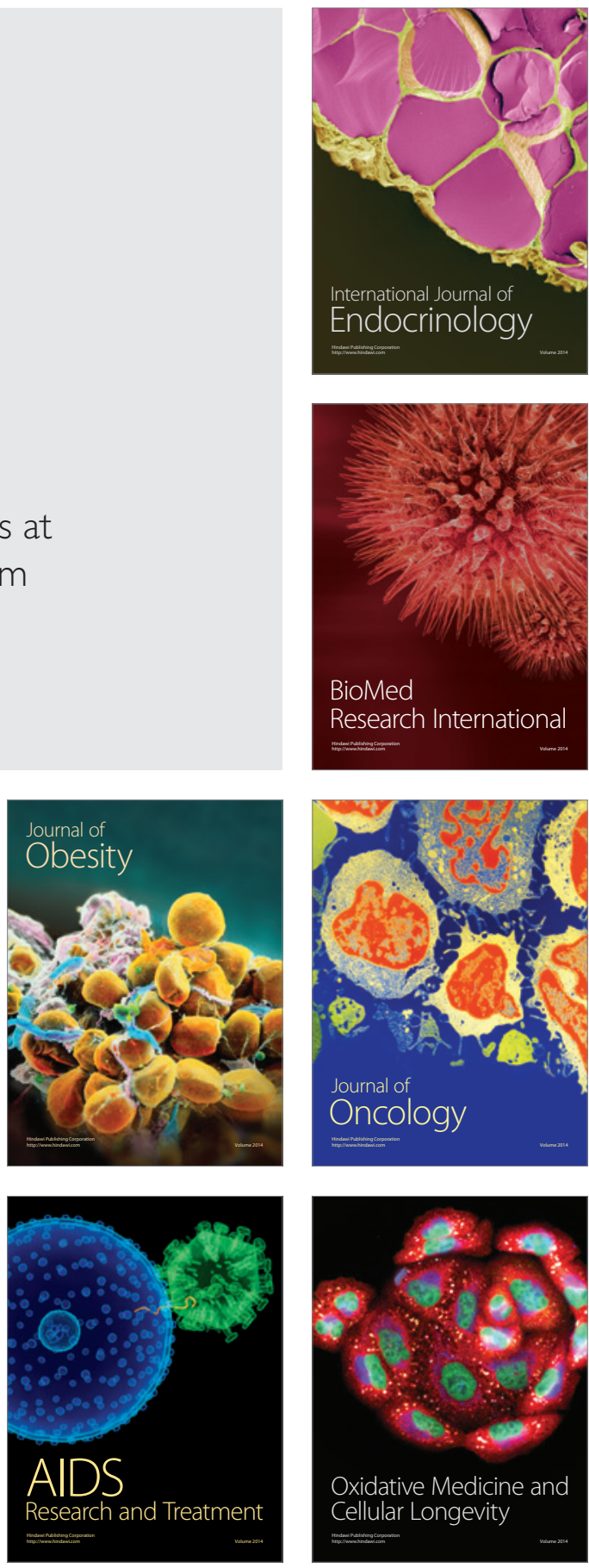